\title{
KEPUASAN PELANGGAN UNTUK PEMBELIAN MOBIL HONDA
}

\author{
Agus Zainul Arifin dan Regan Sutrisno Subagio \\ Program Magister Manajemen Universitas Tarumanagara \\ Email:agusa@pps.untar.ac.id
}

\begin{abstract}
The Indonesia economic grewth slowdown on 2015. It has impacted the competition in the automotive industry in Indonesia. All players have got to implement many strategies to keep them in the automotive business. One of the most common strategy is to how to maintain customer satisfaction. This research aimed to investigate which variables are significant and contribute the most to the customer satisfaction variable. This research was using 5 variables, i.e. product quality, after sales service, brand image, perceived value, and customer satisfaction. The sampling data was customers that used Honda Mobile. The questionnaires were distributed to 200 respondents across Indonesian provinces. Structural Equation model method was used for data processing using Lisrel program for Windows.Finally, the conclusion of this research would help Honda improve its performance to keep its customer satisfaction level high, and win the competition in the Indonesian automotive industry.
\end{abstract}

Keyword: Product Quality, After Sales Service, Brand Image, Perceived Value, Customer Satisfaction.

Abstrak: Pertumbuhan ekonomi Indonesia tahun 2015 mengalami penurunan. Hal ini berdampak pada industri Otomotif Indonesia. Semua produsen mobil menyusun strategi untuk mempertahankan bisnis otomotifnya. Strategi yang banyak dilakukan umumnya diarahkan pada kepuasan pelanggan. Tujuan penelitian ini adalah meneliti variabelvariabel yang mempengaruhi kepuasan pelanggan. Objekpenelitian penelitian ini adalah Kualitas Produk, Pelayanan Purna Jual, Brand Image, Perceived Value, dan Kepuasan Pelanggan. Sampel data adalah pengguna produk mobil Honda. Kuesioner disebarkan pada 200 responden di seluruh Indonesia. Analisis data dengan menggunakan metode Structural Equation model.Kesimpulan yang diperoleh membantu produsen Honda mampu mempertahankan kepuasan pelanggan pada level tinggi dan memenangkan persaingan pada industri otomotif di Indonesia.

Kata kunci: Kualitas Produk, Pelayanan Purna Jual, Brand Image, Perceived Value, Kepuasan Pelanggan

\section{PENDAHULUAN}

Pertumbuhan ekonomi dunia yang melambat sejak pertengahan 2013 hingga kuartal I 2014 telah melanda sejumlah negara berkembang, namun Indonesia dapat dikatakan selamat dari dampak perlambatan ekonomi itu. Bahkan menurut Staf Khusus Presiden RI Firmanzah, rilis Badan Pusat Statistik (BPS) neraca perdagangan Indonesia menunjukkan fundamental ekonomi terus membaik.

Di tengah perkembangan ekonomi Indonesia yang masih tergolong baik tersebut, Industri otomotif pun tumbuh berkembang menjadi suatu bidang usaha/bisnis yang patut diperhitungkan dalam kehidupan ekonomi di Indonesia. Salah satu pelaku industri 
otomotif di Indonesia yang bekinerja baik adalah Honda. Hal ini dapat terlihat dari pertumbuhan penjualan Honda pada tahun 2014 yang membukukan angka tertinggi dibandingkan dengan lima merek otomotif lain.

Pertumbuhan ekonomi Indonesia tahun 2015 mengalami pelambatan. Badan Pusat Statistik (BPS) telah merilis pertumbuhan ekonomi kuartal I-2015 sebesar 4,71 persen, melambat dibanding pertumbuhan ekonomi pada periode sama tahun lalu yang mencapai 5,14 persen. (bisniskeuangan.kompas.com, 2015). Hal ini berdampak pada penjualan kendaraan di Indonesia. Penjualan otomotif di tingkat ritel (retail sales) periode JanuariMei 2015 tercatat 486.172 unit, jauh di bawah penjualan Januari-Mei 2014 yang sebanyak 501.313. (CNN Indonesia, 2015).

Penjualan yang menurun tersebut tentunya akan menaikan tingkat persaingan yang terjadi. Meski demikian, Honda tetap optimis dan tidak menurukan target penjualannya. Demi memenuhi target penjualan tersebut, Honda telah mempersiapkan berberapa strategi seperti penambahan produk baru berupa Crossover Utility Vehicle (CUV) Honda HR-V dan Honda BR-V.Selain itu Honda akan melakukan penambahan dealer dan sub dealer dengan fasilitas sales, service, dan sparepart (3S) menjadi 195 sampai 200 dealer, dari sebelumnya 136 dealer. Strategi lainnya yang tidak kalah penting adalah dengan menghadirkan berbagai aktivitas untuk konsumen, serta aktivitas motorsport seperti berpartisipasi di ajang F1, world champhionship, hingga regional championship. (Berita Satu, 2015).

Berbagai strategi yang dilakukan Honda tersebut bertujuan untuk memuaskan konsumennya. Hal tersebut sejalan dengan teori Kotler Keller (2011) mengenai Modern Customer Centric Organization, yaitu perusahan yang berorientasi konsumen akan menciptakan keunggulan bersaing dibanding kompetitor lain yang pada akhirnya dapat membantu Honda untuk bersaing dalam industri otomotif di Indonesia.

Sehubungan dengan uraian pada pendahuluan, Penelitian ini menganalisa variabel yang mempengaruhi kepuasan pelanggan. Hasil dari analisa ini diharapkan akan memberikan kesempatan kepada Honda untuk meningkatkan/mempertahankan kinerja dalam menciptakan kepuasan pelanggan yang tinggi.

Masalah penelitian ini adalah melihat pengaruh kualitas produk terhadap citra merek,persepsi nilai, dan kepuasan pelanggan. pengaruh layanan purna jual terhadap persepsi nilai, dan pengaruh persepsi nilai terhadap kepuasan pelanggan. Model penelitian ini adalah replikasi model yang dilakukan oleh Joanna dan Robert Waligora (2007) untuk subjek penelitian yang sama.

\section{KAJIAN TEORI}

Perilaku Konsumen (Consumer Behavior). Kotler dan Keller (2011) menjelaskan perilaku konsumen adalah suatu pembelajaran bagaimana seseorang individu, grup, dan organisasi memilih, membeli, menggunakan, dan menyingkirkan suatu barang, jasa, ide, atau pengalaman untuk memuaskan kebutuhan dan keinginan mereka. Schiffman dan Kanuk (2009) menyatakan perilaku yang diperlihatkan para konsumen dalam mencari, membeli, menggunakan, mengevaluasi, dan menempatkan produk dan jasa yang diharapkan dapat memenuhi kebutuhan pribadi mereka. Dharmmesta dan Handoko (2012) mendefinisikan perilaku konsumen sebagai sebagai kegiatan-kegiatan individu yang secara langsung terlibat dalam mendapatkan dan mempergunakan barang-barang dan jasa- 
jasa, termasuk di dalamnya proses pengambilan keputusan pada persiapan dan penentuan kegiatan-kegiatan tertentu.

Sebuah perilaku konsumen dipengaruhi oleh kultur, sosial, dan faktor personal. Dari kesemuanya itu, kultur memberikan pengaruh yang paling dalam pada perilaku konsumen. Kultur merupakan fundamental dari keinginan dan tingkah laku seseorang. Pemasar yang mengerti perilaku konsumen akan mampu memperkirakan bagaimana kecenderungan konsumen untuk bereaksi terhadap informasi yang diterimanya, sehingga pemasar dapat menyusun strategi pemasaran yang sesuai. Tidak dapat diragukan lagi bahwa pemasar yang memahami konsumen akan memiliki kemampuan bersaing yang lebih baik.

Kualitas Produk. Kotler dan Keller (2011) menggunakan pengertian kualitas menurut American Society of Quality yaitu jumlah total fitur dan karakteristik dari sebuah produk atau jasa yang muncul dari kemampuan produk atau jasa tersebut dalam memenuhi kepuasan yang dijanjikan dan pemenuhan kebutuhan yang ada. Pengertian produk menurut Tjiptono (2007) adalah hasil atau keluaran yang berwujud fisik dari proses transformasi sumber daya, sehingga dapat dilihat, diraba/disentuh, dirasa, dipegang, disimpan, dipindahkan dan mendapat perlakuan fisik lainnya. Garvin (2003) mengungkapkan ada delapan dimensi kualitas produk. Gaspersz (2006) menyebutnya ada delapan dimensi. Mullins et al. (2009) membagi dimensi kualitas produk terdiri dari: (1) Kinerja, yaitu berhubungan dengan karakteristik operasi dasar dari sebuah produk; (2) Daya tahan, yang berarti berapa lama umur produk bertahan sebelum produk tersebut harus diganti; (3) Kesesuaian dengan spesifikasi, yaitu sejauh mana produk memenuhi spesifikasi atau tidak ditemukannya cacat pada produk; (4) Fitur, adalah karakteristik produk yang dirancang untuk menyempurnakan fungsi produk atau ketertarikan konsumen terhadap produk; (5) Reliabilitas, adalah probabilitas bahwa produk akan bekerja dengan memuaskan atau tidak dalam periode waktu tertentu; (5) Estetika, berhubungan dengan bagaimana penampilan produk.

Selain itu, ada kebutuhan untuk mempertimbangkan satu dimensi yang lebih berkualitas yaitu, keamanan. Keamanan sering diabaikan dalam pembicaraan mengenai sebuah kualitas. Sebuah produk yang tidak aman tidak dapat dianggap sebagai produk yang berkualitas (Sethi, 2000).

Layanan Purna Jual (After Sales Service). Kotler dan Keller (2011) menyatakan layanan purna jual adalah layanan yang diberikan perusahaan kepada seorang konsumen setelah terjadinya transaksi penjualan. Hindle (2008) menjelaskan layanan purna jual adalah suatu layanan yang disediakan oleh produsen kepada konsumen setelah konsumen tersebut membeli produk dari perusahaan tersebut. Sudarsono dan Edilius (2010) mendefinisikan layanan purna jual sebagai jasa layanan yang meliputi perbaikan, penyediaan suku cadang, dan lain-lain yang diberikan oleh perusahaan kepada konsumen setelah produknya dibeli untuk jangka waktu tertentu.

Kotler dan Armstrong (2012) menjelaskan bahwa unsur-unsur dalam layanan purna jual adalah: (1) Garansi, ditunjukan untuk meyakinkan konsumen bahwa produk dalam keadaan baik atau bebas dari kerusakan, akibat dari ketidaktelitian pengarjaan atau penggunaan material yang kurang baik yang berlaku untuk jangka waktu tertentu; (2) Penyediaan Aksesoris, dalam pelaksanaan layanan purna jual, penyediaan suku cadang merupakan hal yang sangat penting, sebab tanpa adanya suku cadang produk yang sudah rusak komponennya tidak dapat berfungsi dengan baik, bahkan produk tersebut tidak dapat dipakai lagi; (3) Layanan Pemeliharaan dan Perbaikan,diperlukan apabila suatu 
produk memiliki masa konsumsi yang lama dan memerlukan perawatan yang teratur agar dapat selalu berfungsi dengan baik, dan juga untuk melakukan perbaikan atas kerusakan yang terjadi pada produk tersebut selama pemakaiannya; (4) Fasilitas dan Perlengkapan Fasilitas dan perlengkapan suatu produk merupakan sarana untuk melakukan layanan purna jual. Peralatan dan perlengkapan yang canggih akan dapat menentukan kelancaran layanan petugas dalam melakukan pemeliharaan dan perbaikan produk yang dibeli konsumen.

Citra Merk (BrandImage). Keller (2008) mendefinisikan Citra merek adalah persepsi pelanggan terhadap merek, seperti yang tercermin oleh asosiasi merek (brand association) yang ada dalam ingatan pelanggan. Arti asosiasi merek sendiri adalah informasi tentang merek yang tersimpan dalam ingatan dan mengandung arti merek tersebut bagi pelanggan. Durianto et al. (2003) menyatakan citra merek adalah asosiasi merek saling berhubungan dan menimbulkan suatu rangkaian dalam ingatan konsumen. Aaker (2008) menjelaskan bahwa Asosiasi ini mengacu pada setiap aspek merek dalam ingatan konsumen .

Citra merek selalu berkaitan dengan atribut produk karena untuk memberikan kepuasan kepada konsumen dan konsumen bereaksi terhadap atribut produk yang dibelinya. Atribut yang digunakan yaitu (Kotler dan Keller, 2011): (1) Rasa, Seperti dari makanan yang disajikan kepada konsumen merupakan salah satu faktor yang menentukan citra suatu merek dari produk. Biasanya sebelum melakukan pembelian konsumen akan melihat terlebih dahulu penampilan dari makanan yang disajikan. Selanjutnya apabila penampilan makanan tersebut menarik hatinya konsumen akan melakukan pembelian; (2) Kemasan, menurut Kotler dan Keller (2011) pengemasan mencakup semua kegiatan merancang dan memproduksi wadah atau pembungkus untuk suatu produk. Kemasan yang didesain dengan menarik secara otomatis akan menarik perhatian konsumen pula; (3) Harga, merupakan jumlah uang yang harus konsumen bayarkan sebagai kompensasi produk yang diperoleh dari prusahaan.

Faktor-faktor yang membentuk citra merek Menurut Schiffman dan Kanuk (2009) adalah: (1) Kualitas atau mutu, berkaitan dengan kualitas produk yang ditawarkan oleh produsen dengan merek tertentu; (2) Dapat dipercaya atau diandalkan, berkaitan dengan pendapat dan kesepakatan yang di bentuk oleh masyarakat tentang suatui produk yang dikonsumsi; (3) Kegunaan atau manfaat, yang terkait dengan fungsi dari suatu produk yang bisa dimanfaatkan oleh konsumen; (4) Layanan, yang berkaitan dangan tugas produsen dalam melayani konsumennya; (5) Resiko berkaitan dengan untung rugi yang dialami oleh konsumen; (6) Harga, dalam hal ini berkaitan dengan tinggi rendahnya atau banyak sedikitnya jumlah uang yang dikeluarkan konsumen untuk mempengaruhi suatu produk, juga dapat mempengaruhi citra jangka panjang; (7) Citra, yang dimiliki merek itu sendiri, yaitu berupa pelanggan, kesempatan dan informasi yang berkaitan dengan suatu merek dari produk tertentu.

Pada pasar $B 2 B$ (business to business), citra merek juga memainkan peran penting. Hal ini dikarenakan dalam pasar $B 2 B$ nilai produk dan jasa sulit dibedakan berdasarkan atribut nyata.

Persepsi Nilai (Perceived Value). Zeithaml et al.(2006) mendefinisikan Persepsi nilai sebagai trade-off antara manfaat (apa yang diterima) dan pengorbanan (apa yang diberikan) dalam pertukaran pasar.Kotler dan Keller (2011) menjelaskan tentang Persepsi nilai yaitu perbedaan dari manfaat yang telah dievaluasi oleh pelanggan dibandingkan dengan biaya dari sebuah penawaran dan produk alternatif. Zeithaml et al. (2006) 
berpendapat bahwa konsumen akan mengevaluasi apa yang mereka berikan dan apa yang mereka dapatkan dalam persepsi subjektif mereka ketika mereka membeli suatu produk/jasa.

Menurut Sweeney et al. (2000) dimensi persepsi nilai terdiri empat aspek utama: (1) Nilai emosional, yaitu utilitas yang berasal dari perasaan atau afektif /emosi positif yang ditimbulkan dari mengkonsumsi produk; (2) Nilai sosial, yaitu utilitas yang didapatkan dari kemampuan produk untuk meningkatkan konsep diri-sosial Pelanggan; (3) Nilai kualitas, yaitu utilitas yang diperoleh dari persepsi terhadap kualitas dan kinerja yang diharapkan atas produk; (4) Harga/Value of Money, yakni utilitas yang didapatkan dari produk dikarenakan reduksi biaya jangka pendek dan biaya jangka panjang.

Menurut Kotler dan Keller (2011), pelanggan akan membuat pilihan produk yang memberikan persepsi nilai terbesar dengan memaksimalkan keterbatasan pada biaya pencarian, pengetahuan, mobilitas, dan pendapatan.

Kepuasan Pelanggan (Customer Satisfaction). Definisi kepuasan pelanggan menurut Kotler dan Keller (2011) yaitu perasaan senang atau kecewa dari seseorang sebagai hasil perbandingan antara perceived performance(hasil/outcome) yang diterima dari suatu produk dan harapan-harapannya. Jika perceived performance dibawah harapan, maka pelanggan akan kecewa, jika perceived performance melampau harapan, maka pelanggan akan puas.

Dalam literatur, selama ini terdapat dua konsep besar mengenai kepuasan yaitu transaction-specific satisfaction dan cumulative satisfaction (Waligora, 2007). Transaction-specific satisfaction dideskripsikan sebagai evaluasi dari konsumen terhadap pengalaman tunggal dari sebuah produk atau jasa. Kebalikan dari Transaction-specific satisfaction, cumulative satisfaction merupakan penjumlahan dari pengalaman dari seluruh pembelian dan konsumsi dari sebuah produk selama terjadi hubungan dengan produk tersebut (Waligora \& Waligora, 2007).

Penelitian ini lebih berfokus kepada konsep cumulative satisfaction yang dianggap lebih mewakili industri otomotif di Indonesia. Hal ini mempertimbangkan pada industri otomotif di Indonesia yang terdapat pembelian yang sering dan kepuasan pelanggan dinilai dari pengalaman dalam jangka waktu yang panjang.

Pengaruh Kualitas Produk Terhadap Citra Merek. Arslan et al.(2010) menyatakan bahwa salah satu alat pemasaran yang dapat digunakan untuk membangun citra merek adalah, produk itu sendiri. Garvin (2003) mengungkapkan bahwa salah satu dari dimensi kualitas produk adalah kualitas yang dipersepsikan, menyangkut penilaian konsumen terhadap citra, merek, atau iklan. Kualitas yang dipersepsikan sendiri adalah suatu penerimaan konsumen terhadap kualitas suatu produk.

Dengan adanya produk sebagai alat untuk membangun citra merek, maka apabila kualitas suatu produk semakin baik, maka secara langsung hal tersebut akan ikut membangun citra merek menjadi lebih baik. Penilaian Konsumen terhadap citra merek juga turut mempengaruhi kualitas yang dipersepsikan. Dengan demikian konsumen akan mempersepsikan citra merek secara baik apabila kualitas suatu produk dinilai baik.

Hipotesis 1:Kualitas produk berpengaruh positif terhadap citra merek.

Pengaruh Citra Merek Terhadap Persepsi Nilai. Sweeney et al. (2000) menyatakan terdapat nilai emosional dan nilai sosial yang merupakan peran citra merek terhadap persepsi nilai. Koler dan Keller (2011) berpendapat bahwa persepsi nilai merupakan 
perbandingan antara penjumlahan nilai yang diterima oleh konsumen, seperti manfaat produk, manfaat layanan, manfaat personal, manfaat citra dibandingkan dengan total biaya yang dikeluarkan seperti biaya keuangan, biaya waktu, biaya energi, biaya psikologi.

Persepsi nilai merupakan kumpulan setiap nilai yang terdapat pada suatu produk, termasuk citra merek yang turut berkontribusi melalui nilai emosional dan nilai sosial.

Dengan demikian, citra merek yang baik akan menghasilkan nilai emosional dan nilai sosial yang tinggi pada suatu produk, yang pada akhirnya akan menambah persepsi nilai suatu produk secara keseluruhan.

Hipotesis 2: Citra merek berpengaruh positif terhadap persepsi nilai.

Pengaruh Kualitas Produk Terhadap Persepsi Nilai. Aaker (2008) menyatakan bahwa ada tiga nilai yang dijanjikan oleh sebuah produk/jasa, yaitu nilai fungsional, nilai emosional, dan nilai ekspresi diri. Pada akhirnya, nilai fungsional yang diterima oleh konsumen akan membentuk persepsi nilai. Menurut Sweeney et al. (2000) salah satu dari dimensi persepsi nilai adalah nilai kualitas, yaitu utilitas yang diperoleh dari persepsi terhadap kualitas dan kinerja yang diharapkan atas produk. Persepsi nilai konsumen meningkat apabila konsumen merasakan manfaat akan produk tersebut lebih tinggi dibandingkan dengan pengorbanan yang dikeluarkan untuk mendapatkan produk tersebut,

Berdasarkan uraian tersebut, dapat disimpulkan bahwa kualitas produk yang baik akan memiliki nilai fungsionalitas yang baik pula. Kualitas produk yang baik akan memiliki meningkatkan nilai kualitas melalui utilitas yang diperoleh dari persepsi terhadap kualitas dan kinerja yang diharapkan atas suatu produk. Semakin tinggi kualitas suatu produk, maka nilai fungsionalitas dan nilai kualitas akan semakin tinggi. Nilai fungsionalitas dan nilai kualitas yang tinggi akan menciptakan persepsi nilai pelanggan terhadap suatu produk yang baik.

Hipotesis 3: Kualitas produk berpengaruh positif terhadap persepsi nilai.

Pengaruh Kualitas Produk Terhadap Kepuasan Pelanggan. Adapun definisi kepuasan pelanggan menurut Kotler dan Keller (2011) seperti telah dibahas sebelumnya yaitu perasaan senang atau kecewa dari seseorang sebagai hasil perbandingan antara perceived performance(hasil/outcome) yang diterima dari suatu produk dan harapanharapannya.Selain itu, Kotler dan Keller (2011) menyatakan bahwa kepuasan juga akan tergantung pada kualitas produk. Pengertian kualitas menurut American Society of Quality yaitu jumlah total fitur dan karakteristik dari sebuah produk atau jasa yang muncul dari kemampuan produk atau jasa tersebut dalam memenuhi kepuasan yang dijanjikan dan pemenuhan kebutuhan yang ada.

Suatu produk yang baik akan memiliki fitur dan karakteristik yang baik. Semakin baik fitur dan karakteristik suatu produk, maka suatu produk akan lebih mampu untuk memenuhi kepuasan yang dijanjikan dan pemenuhan suatu kebutuhan. Semakin tinggi kemampuan suatu produk untuk memenuhi kepuasan yang dijanjikan dan pemenuhan suatu kebutuhan makan kepuasan pelanggan akan semakin tinggi. Dengan demikian kualitas suatu produk akan memiliki dampak langsung terhadap kepuasan pelanggan. Kualitas produk yang baik akan menghasilkan tingkat kepuasan pelanggan yang tinggi.

Hipotesis 4: Kualitas produk berpengaruh positif terhadap kepuasan pelanggan.

Pengaruh Layanan Purna Jual Terhadap Persepsi Nilai. Menurut Kotler dan Keller (2011) persepsi nilai dibentuk oleh selisih dari total manfaat yang diterima oleh konsumen, dibandingkan dengan seluruh total biaya yang dikeluarkan konsumen untuk 
memperoleh suatu produk/jasa. Hubungan antara layanan purna jual terhadap persepsi nilai juga jelas terlihat pada penelitian yang dilakukan oleh Chen (2013).Pada penelitian tersebut dinyatakan bahwa layanan purna jual mempengaruhi persepsi nilai oleh pelanggan.

Persepsi nilai konsumen meningkat apabila konsumen merasakan manfaat akan produk tersebut lebih tinggi dibandingkan dengan pengorbanan yang dikeluarkan untuk mendapatkan produk tersebut, termasuk pengorbanan selisih manfaat yang didapat dengan produk pesaing. Persepsi nilai merupakan kumpulan setiap nilai yang terdapat pada suatu produk termasuk nilai fungsional yang dibangun oleh kualitas produk yang baik. Dengan adanya komponen dalam persepsi nilai yang merupakan total keseluruhan manfaat, termasuk manfaat dari layanan purna jual. Maka layanan purna jual mempengaruhi persepsi nilai. Semakin pelanggan puas terhadap layanan purna jual yang diberikan, maka manfaat yang diberikan akan semakin baik. Semakin baik manfaat yang diterima oleh pelanggan, maka persepsi nilai pelanggan terhadap suatu produk akan semakin tinggi.

Hipotesis 5: Layanan purna jual berpengaruh positif terhadap persepsi nilai.

Pengaruh Persepsi Nilai Terhadap Kepuasan Pelanggan. Pada penelitian yang dilakukan oleh Hawkins et al. (2007) menyatakan bahwa persepsi nilai merupakan pengerak utama kepuasan pelanggan. Hal ini sesuai dengan teori oleh Kotler dan Keller (2011), dimana persepsi nilai dan kepuasan pelanggan sejalan dalam membentuk hubungan dan loyalitas jangka panjang.

Menurut Kotler dan Keller (2011) kepuasan pelanggan yaitu perasaan senang atau kecewa dari seseorang sebagai hasil perbandingan antara perceived performance (hasil/outcome) yang diterima dari suatu produk dan harapan-harapannya. Perceived performance merupakan suatu nilai di dalam persepsi nilai. Persepsi nilai konsumen meningkat apabila konsumen merasakan manfaat akan produk tersebut lebih tinggi dibandingkan dengan pengorbanan yang dikeluarkan untuk mendapatkan produk tersebut, termasuk pengorbanan selisih manfaat yang didapat dengan produk pesaing. Persepsi nilai merupakan kumpulan setiap nilai yang terdapat pada suatu produk termasuk nilai fungsional yang dibangun oleh kualitas produk yang baik.

Dengan demikian, Persepsi nilai yang baik akan menstimulasi kepuasan pelanggan. Semakin tinggi seorang pelanggan mempersepsikan nilai suatu produk, maka seorang pelanggan merasa menerima manfaat yang semakin besar dibandingkan biaya yang dikeluarkan. Semakin besar manfaat yang diterima dibandingkan biaya yang dikeluarkan akan kepuasan pelanggan akan semakin tinggi.

Hipotesis 6:Persepsi nilai berpengaruh positif terhadap kepuasan pelanggan.

Kerangka Pemikiran. Model yang digunakan dalam penelitian ini merupakan bagian dari model yang oleh Waligora dan Waligora (2007) pada industri otomitif di Polandia. Mereka menganalisis dengan menggunakan metode Brand Satisfaction Model. Penelitian tersebut menemukan bahwa pada perusahaan X di Polandia, pengaruh terkuat terhadap kepuasan pelanggan berasal dari kualitas produk, melebihi pengaruh dari persepsi nilai. Pengaruh terbesar pada persepsi nilai secara berurutan disumbang dari kualitas produk, layanan purna jual, dan citra merek. Selain itu ditemukan juga bahwa kualitas produk berpengaruh terhadap citra merek.

Sebagai referensi lainnya, digunakan juga penelitian yang dilakukan oleh Octavia (2010). Dengan judul Analisa Tingkat Kepuasan Pengguna Mobil Toyota di Jakarta. Penelitian tersebut meneliti tingkat kepuasan pengguna mobil Toyota di Jakarta. Variabel 
yang digunakan dalam penelitian tersebut terdiri dari tujuh variable, yaitu: Produk, Sales Activity, After Sales Activity, Culture, Brand, Promotion, dan Consumer. Paundrine Octavia menemukan bahwa sebagian besar pengguna Toyota mengaku puas dengan produk Toyota. Variabel Produk dan After Sales Activity memiliki pengaruh yang kuat terhadap kepuasan pelanggan. Gambar 1 merupakan kerangka Pemikiran dan hipotesis penelitian yang menjelaskan pengaruh antara valiabel-variabel penelitian.

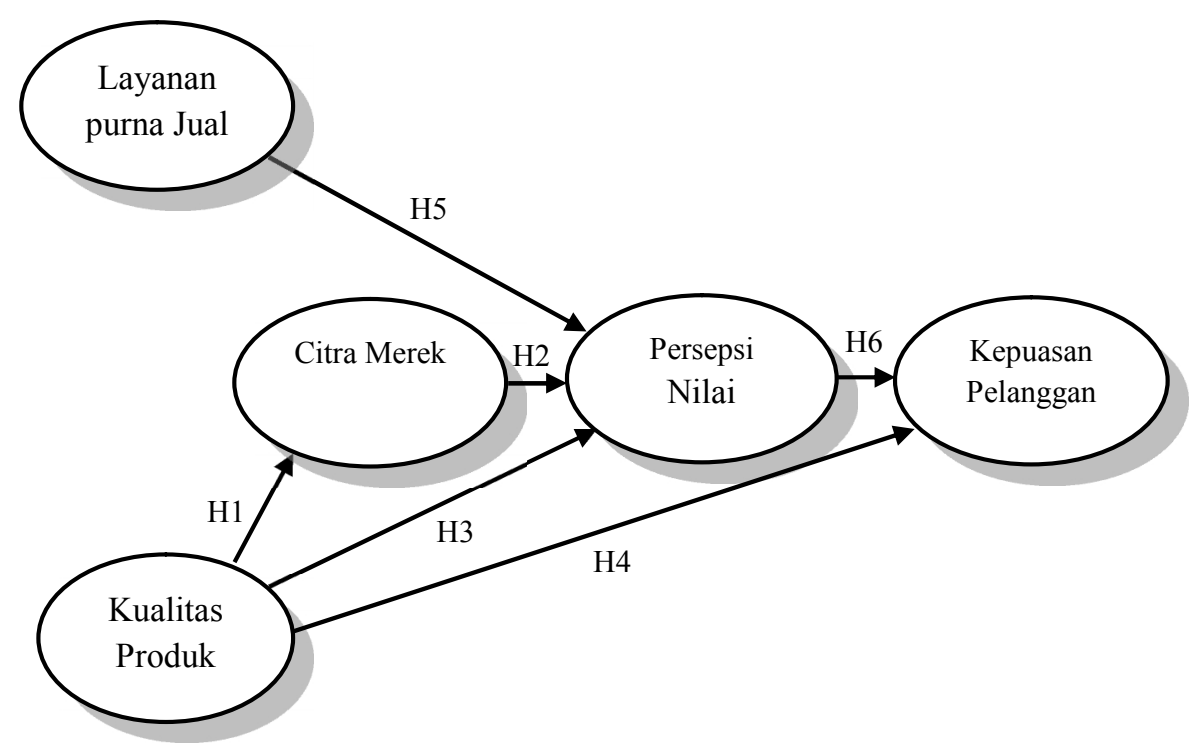

Gambar 1. Kerangka Pemikiran

\section{METODE}

Subjek dan Objek Penelitian. Untuk itu subjek penelitian yang digunakan adalah seluruh pengguna mobil Honda di Indonesia. Sedangkan objek dalam penelitian ini adalah sebagai berikut: (1) Kepuasan pelanggan dalam menggunakan mobil Honda; (2) Persepsi nilai Honda yang dirasakan oleh konsumen; (3) Citra merek Honda di benak pengguna mobil Honda; (4) Kualitas pelayanan purna jual yang diterima oleh pengguna mobil Honda; (5) Kualitas produk yang dirasakan oleh pengguna mobil Honda.

Disain Penelitian. Disain penelitian merupakan dasar dalam membuat penelitian. Penelitian ini menggunakan studi deskriptif dan perifikatif. Populasinya adalah pengguna kendaraan mereh Honda di Indonesia. Metode sampling yang digunakan adalah metode probability sampling dengan simple random sampling. Sampling dilakukan dengan menyebarkan kuesioner secara acak pada responden di seluruh Indonesia. Data yang digunakan berupa data primer berupa kuesioner yang harus diisi oleh responden. Responden diminta untuk mengisi kuesioner berupa pilihan tertutup dengan skala Likert

Operasionalisasi Variabel. Penelitian ini akan menggunakan lima variabel. Indikator dalam penelitian ini merupakan adopsi dari penelitian terdahulu, terutama penelitian yang dilakukan oleh Berikut ini adalah variabel dan indikator yang digunakan dalam penelitian ini yang bersumber dari penelitian yang dilakukan oleh Waliǵora dan Waligora (2007): Pertama. Variabel kualitas produk diukur dengan delapan indikator, yakni: (a) Kualitas keseluruhan dari kendaraan anda baik; (b) Kendaraan anda dapat diandalkan; (c) 
Kendaraan anda memiliki kualitas pengecatan yang baik; (d) Kendaraan anda memiliki kualitas \& bahan interior yang baik; (e) Kendaraan anda memiliki kualitas langit-langit yang baik; (f) Kendaraan anda memiliki kualitas pengendalian yang baik; (g) Kendaraan anda memiliki kualitas suspensi yang baik; (h) Kendaraan anda memiliki kualitas pengereman yang baik. Kedua. Variabel layanan purna jual diukur dengan tujuh indikator, yakni: (a) Anda puas dengan pelayanan purna jual secara keseluruhan; (b) Service advisor bersikap profesional; (c) Service advisor bersikap informatif; (d) Bengkel servis memiliki suasana yang baik; (e) Tersedia mobil pengganti; (f) Sparepartready stock; (g) Ketepatan janji dari service advisor dipenuhi secara tepat. Ketiga. Variabel citra merek diukur dengan sembilan indikator, yakni: (a) Honda memiliki citra yang baik; (b) Anda merasa aman ketika mengendarai Honda; (c) Merk Honda stabil dalam industri otomotif; (d) Honda unggul dalam teknologi; (e) Honda mendengarkan masukan dari konsumen; (f) Honda terlibat aktif dalam kegiatan sosial; (g) Honda rutin melakukan promosi (Iklan, sponsorship, dsb); (h) Honda aktif dalam kegiatan peduli lingkungan; (i) Honda membuat kehidupan pengemudi lebih mudah. Keempat. Variabel persepsi nilai diukur dengan skala empat indikator, yakni: (a) Anda mendapatkan kesepakatan harga yang baik pada saat pembelian; (b) Dibandingkan dengan manfaatnya, kendaraan anda memiliki harga murah; (c) Dibandingkan dengan kualitasnya, kendaraan anda memiliki harga murah; (d) Honda memberikan nilai lebih banyak dari perusahaan pesaing. Kelima. Variabel kepuasan pelanggan diukur dengan tiga indikator, yakni: (a) Anda puas menggunakan kendaraan anda; (b) Kendaraan anda merupakan kendaraan yang ideal; (c) Bayangan tentang mobil yang anda harapkan dapat terpenuhi dengan baik oleh kendaraan Honda yang anda beli.

Pengambilan Data. Metode pengumpulan data primer dilakukan melalui penyebaran kuisioner. Kuisioner dibentuk dengan dua bagian. Bagian pertama berisi pertanyaan untuk mengetahui demografi dan profil responden. Bagian kedua berisi pernyataan untuk mengukur atribut-atribut yang sedang diteliti. Kuisioner format kedua disusun dalam skala likert yang mempunyai lima pilih Adapun bobot nilai jawabannya adalah sebagai berikut (Tabel 1):

Tabel 1. Alternatif Jawaban Responden

\begin{tabular}{cc}
\hline Alternatif Jawaban & Bobot Nilai \\
\hline Sangat Setuju & 5 \\
Setuju & 4 \\
Netral & 3 \\
Tidak Setuju & 2 \\
Sangat Tidak Setuju & 1 \\
\hline
\end{tabular}

Analisis Statistik. SEM merupakan pendekatan terintegrasi antara analisis data dan konstruksi konsep. Dalam penelitian ini, perangkat lunak yang digunakan dalam analsis SEM adalah Lisrel. Sebuah pemodelan SEM yang lengkap pada dasarnya terdiri dari measurement model dan structural model.

Pada tahap structural model dilakukan penilaian model fit. Terdapat beberapa kriteria yang perlu dipenuhi untuk menilai sebuah model fit atau tidak. Berilkut ini disajikan kriteria Goodness of fit dalam Metode analisis SEM (Wijanto, 2015) seperti tertera pada Tabel 2. 
Tabel 2. Kriteria Goodness of Fit

\begin{tabular}{cc}
\hline Fit Measurement & Fit Measures \\
\hline Chi-square & Semakin kecil semakin baik \\
GFI & $0,8 \leq \mathrm{GFI} \leq 0,9=$ marginal fit; GFI $>0,9=$ good fit \\
RMR & RMR $\leq 0,05=$ good fit \\
RMSEA & RMSEA $\leq 0,08=$ good fit; RMSEA $<0,05=$ close fit \\
NNFI & $0,8 \leq \mathrm{NNFI} \leq 0,9=$ marginal fit; NNFI $>0,9=$ good fit \\
NFI & $0,8 \leq \mathrm{NFI} \leq 0,9=$ marginal fit; NFI $>0,9=$ good fit \\
AGFI & $0,8 \leq \mathrm{AGFI} \leq 0,9=$ marginal fit; AGFI $>0,9=$ good fit \\
RFI & $0,8 \leq \mathrm{RFI} \leq 0,9=$ marginal fit; RFI $>0,9=$ good fit \\
IFI & $0,8 \leq \mathrm{IFI} \leq 0,9=$ marginal fit; IFI $>0,9=$ good fit \\
CFI & $0,8 \leq \mathrm{CFI} \leq 0,9=$ marginal fit; CFI $>0,9=$ good fit \\
\hline
\end{tabular}

Sumber: Wijanto, (2015)

\section{HASIL DAN PEMBAHASAN}

Deskripsi Responden. Dari 200 Kuisioner yang dianalisis, diketahui bahwa 65,5 persen responden berjenis kelamin laki-laki dan 35,5 persen responden perempuan. Berdasarkan tipe mobil, sebanyak 30,5 persen responden menggunakan tipe MPV, 28 persen responden tipe city car, 27 persen responden tipe SUV, dan 14,5 persen responden tipe sedan.

Berdasarkan tahun kendaraan, sebanyak 61 persen responden menggunakan mobil Honda keluaran setelah tahun 2012, 10 persen responden tahun 2009 sampai dengan 2011, 9,5 persen responden tahun 2006 sampai dengan 2008, 13 persen responden tahun 2003 sampai dengan 2005, dan 6,5 persen responden sebelum tahun 2003. Berdasarkan usia responden, sebanyak 12 persen responden berusia dibawah 25 tahun, 58,5 persen responden berusia 26 sampai dengan 35 tahun, 22 persen responden berusia 36 sampai dengan 45 tahun, 7 persen responden berusia 46 sampai dengan 55 tahun dan 0,5 persen responden berusia diatas 55 tahun. Berdasarkan tingkat pendidikan, sebanyak 9 persen responden menyelesaikan pendidikan hingga SMA, 67 persen responden tingkat D1 hingga S1 20,5 persen tingkat S2, dan 3,5 persen responden tingkat S3.

Berdasarkan kehidupan keluarga, sebanyak 17 persen responden tinggal sendiri, 9 persen tinggal berdua, 44,5 persen responden tinggal bersama dua hingga tiga orang lain, 20 persen responden tinggal berdua, 20 persen responden tinggal bersama empat hingga lima orang lain, dan 9,5 persen responden tinggal bersama lebih dari lima orang dalam satu rumah. Berdasarkan jenis pekerjaan, sebanyak 3 persen responden belum atau tidak bekerja, 70 persen responden bekerja sebagai karyawan swasta, 0.5 persen responden bekerja sebagai PNS, 14 persen bekerja sebagai professional, dan 14 persen responden bekerja pada bidang pekerjaan pekerjaan lainnya.

Berdasarkan tempat tinggal, sebanyak 72.5 persen responden tinggal di Jabodetabek, 7 persen responden di pulau Sumatera, 7 persen responden di pulau Kalimantan dan pulau Sulawesi, 14.5 persen responden di pulau Jawa (di luar Jabodetabek) dan Bali, 6 persen responden di tempat lain di Indonesia.

Berdasarkan pendapatan kotor per bulan, sebanyak 21 persen responden memiliki pendapatan sampai dengan 6 juta Rupiah per bulan, 18,5 persen responden diatas 6 juta rupiah sampai dengan 10 juta rupiah per bulan, 28 persen responden diatas 10 juta rupiah sampai dengan 20 juta rupiah per bulan, 21 persen responden diatas 10 juta rupiah sampai dengan 20 juta rupiah per bulan, dan 11,5 persen responden diatas 30 juta rupiah per bulan. 
Deskripsi Variabel Penelitian. Berdasarkan hasil dari kuisioner yang dikumpulkan, dapat diketahui bahwa frekuensi responden terhadap variabel kualitas produk (PROD) didominasi oleh jawaban setuju. Terdapat satu responden yang sangat tidak setuju dengan pernyataan PROD1, yaitu pernyataan "Kualitas keseluruhan dari kendaraan anda baik". Terdapat tiga responden yang sangat tidak setuju dengan pernyataan PROD3, yaitu pernyataan "Kendaraan anda memiliki kualitas pengecatan yang baik". Terdapat empat responden yang sangat tidak setuju dengan pernyataan PROD4, yaitu pernyataan "Kendaraan anda memiliki kualitas \& bahan interior yang baik".

Frekuensi responden terhadap variabel layanan purna jual (PJ) didominasi oleh jawaban setuju. Terdapat masing-masing satu responden yang sangat tidak setuju dengan pernyataan PJ2, PJ3, dan PJ4, yaitu pernyataan "Service advisor bersikap profesional", "Service advisor bersikap informatif", dan "Bengkel servis memiliki suasana yang baik". Terdapat dua responden yang sangat tidak setuju dengan pernyataan PJ6, yaitu pernyataan "Sparepartready stock". Terdapat tiga responden yang sangat tidak setuju dengan pernyataan PJ7, yaitu pernyataan "Ketepatan janji dari service advisor dipenuhi secara tepat".

Frekuensi responden terhadap variabel citra merek (CIT) didominasi oleh jawaban setuju. Terdapat masing-masing satu responden yang sangat tidak setuju dengan pernyataan CIT2 dan CIT8, yaitu pernyataan "Anda merasa aman ketika mengendarai Honda" dan "Honda membuat kehidupan pengemudi lebih mudah". Terdapat tiga responden yang sangat tidak setuju dengan pernyataan CIT4, yaitu pernyataan "Honda unggul dalam teknologi".

Frekuensi responden terhadap variabel persepsi nilai (PN) didominasi oleh jawaban setuju. Terdapat masing-masing satu responden yang sangat tidak setuju dengan pernyataan PN3 dan PN4, yaitu pernyataan "Dibandingkan dengan kualitasnya, kendaraan anda memiliki harga murah" dan "Honda memberikan nilai lebih banyak dari perusahaan pesaing"

Frekuensi responden terhadap variabel kepuasan pelanggan (PUAS) didominasi oleh jawaban setuju. Pada kolom tidak setuju, terdapat enam responden yang tidak setuju dengan pernyataan PUAS1, yaitu pernyataan "Anda puas menggunakan kendaraan anda", 18 responden yang tidak setuju dengan pernyataan PUAS2, yaitu pernyataan "Kendaraan anda merupakan kendaraan yang ideal", 22 responden yang tidak setuju dengan pernyataan PUAS3, yaitu pernyataan "Bayangan tentang mobil yang anda harapkan dapat terpenuhi dengan baik oleh kendaraan Honda yang anda beli".

Uji Validitas. Uji validitas dilakukan sebagi pre-test sebelum kuisioner digunakan lebih lanjut. Uji validitas menggunakan sampel yang diambil dari 30 responden menggunakan program SPSS versi 2.1. Secara keseluruhan, hasil dari uji validitas dapat dilihat dari Tabel 3:

Tabel 3. Hasil Uji Validitas Secara Keseluruhan

\begin{tabular}{ccc}
\hline Variabel & Nama Indikator & Hasil Uji Validitas \\
\hline & PROD1 & VALID \\
Kualitas Produk & PROD2 & VALID \\
(PROD) & PROD3 & VALID \\
& PROD4 & VALID \\
& PROD5 & VALID \\
\hline
\end{tabular}




\begin{tabular}{ccc} 
Lanjutan Tabel 3 & & \\
\cline { 2 - 3 } & PROD6 & VALID \\
& PROD7 & VALID \\
& PROD8 & VALID \\
& PJ1 & VALID \\
& PJ2 & VALID \\
Layanan Purna & PJ3 & VALID \\
Jual (PJ) & PJ4 & VALID \\
& PJ5 & TIDAK VALID \\
& PJ6 & VALID \\
& PJ7 & VALID \\
& CIT1 & VALID \\
& CIT2 & VALID \\
& CIT3 & VALID \\
Citra (CIT) & CIT4 & VALID \\
& CIT5 & TIDAK VALID \\
& CIT6 & TIDAK VALID \\
& CIT7 & VALID \\
& CIT8 & VALID \\
& CIT9 & VALID \\
& PN1 & VALID \\
Persepsi Nilai & PN2 & VALID \\
(PN) & PN3 & VALID \\
& PN4 & VALID \\
Kepuasan & PUAS1 & VALID \\
Pelanggan & PUAS2 & VALID \\
(PUAS) & PUAS3 & VALID \\
\hline
\end{tabular}

Uji Reliabilitas. Secara keseluruhan, hasil dari uji reliabilitas dapat dilihat dari Tabel 4.

Tabel 4. Hasil Uji Reliabilitas Secara Keseluruhan

\begin{tabular}{lc}
\hline \multicolumn{1}{c}{ Variabel } & Hasil Uji Reliabilitas \\
\hline Kualitas Produk (PROD) & Reliabel \\
Layanan Purna Jual (PJ) & Reliabel \\
Citra (CIT) & Reliabel \\
Persepsi Nilai (PN) & Reliabel \\
Kepuasan Pelanggan (PUAS) & Reliabel \\
\hline
\end{tabular}

Variabel, indikator dan simbol tiap indikator yang digunakan dalam penelitian ditunjukkan pada Tabel 5.

Tabel 5. Variabel dan Indikator Yang Digunakan Dalam Penelitian

\begin{tabular}{crl}
\hline \multirow{2}{*}{ Variabel } & \multicolumn{2}{c}{ Indikator } \\
\cline { 2 - 3 } & Nama & \\
& PROD1 & Kualitas keseluruhan dari kendaraan anda baik \\
Kualitas & PROD2 & Kendaraan anda dapat diandalkan \\
Produk & PROD3 & Kendaraan anda memiliki kualitas pengecatan yang baik \\
(PROD) & PROD4 & Kendaraan anda memiliki kualitas \& bahan interior yang baik \\
& Kendaraan anda memiliki kualitas langit-langit yang baik \\
& PROD6 & Kendaraan anda memiliki kualitas pengendalian yang baik \\
\hline
\end{tabular}




\begin{tabular}{cll}
\hline \hline Lanjutan Tabel 5 & & \\
& PROD7 & Kendaraan anda memiliki kualitas suspensi yang baik \\
& PROD8 & Kendaraan anda memiliki kualitas pengereman yang baik \\
& PJ1 & Anda puas dengan pelayanan purna jual secara keseluruhan \\
Layanan & PJ2 & Service advisor bersikap professional \\
Purna Jual & PJ3 & Service advisor bersikap informative \\
(PJ) & PJ4 & Bengkel servis memiliki suasana yang baik \\
& PJ6 & Sparepart ready stock \\
& PJ7 & Ketepatan janji dari service advisor dipenuhi secara tepat \\
& CIT1 & Honda memiliki citra yang baik \\
& CIT2 & Anda merasa aman ketika mengendarai Honda \\
CIT3 & Merk Honda stabil dalam industri otomotif \\
Citra (CIT) & CIT4 & Honda unggul dalam teknologi \\
& CIT7 & Honda rutin melakukan promosi (Iklan, sponsorship, dsb) \\
& CIT8 & Honda aktif dalam kegiatan peduli lingkungan \\
& CIT9 & Honda membuat kehidupan pengemudi lebih mudah \\
& PN1 & $\begin{array}{l}\text { Anda mendapatkan kesepakatan harga yang baik pada saat } \\
\text { pembelian }\end{array}$ \\
& PN2 & Dibandingkan dengan manfaatnya, kendaraan anda memiliki \\
harga murah
\end{tabular}

Analisis Structural Equation Model (SEM). Dalam Analisis SEM, perlu dilakukan suatu analisis CFA untuk mengetahui besar loading factor masing-masing indikator terhadap variabelnya. Setelah tiap indikator dianggap valid, selanjutnya akan dibahas evaluasi kriteria goodness of fit untuk mengukur kecocokan sebuah model, analisis model struktural untuk mengetahui bagaimana pengaruh variabel laten, analisis hipotesis untuk menguji hipotesis yang telah ditetapkan sebelumnya, dan analisis koefisien determinasi $\left(\mathrm{R}^{2}\right)$ untuk mengukur seberapa jauh kemampuan suatu model dalam menjelaskan variasi variabel dependennya.

Confirmatory Factor Analysis (CFA). Besaran loading factor masing-masing indikator ditampilkan pada Tabel 6.

Tabel 6. Loading Factor Indikator Penelitian

\begin{tabular}{cccccccc}
\hline Indikator & $\begin{array}{c}\text { Loading } \\
\text { Factor }\end{array}$ & Indikator & $\begin{array}{c}\text { Loading } \\
\text { Factor }\end{array}$ & Indikator & $\begin{array}{c}\text { Loading } \\
\text { Factor }\end{array}$ & Indikator & $\begin{array}{c}\text { Loading } \\
\text { Factor }\end{array}$ \\
\hline PUAS1 & 0,60 & PROD5 & 0,79 & PN4 & 0,72 & CIT1 & 0,76 \\
PUAS2 & 0,87 & PROD6 & 0,83 & PJ1 & 0,78 & CIT2 & 0,79 \\
PUAS3 & 0,81 & PROD7 & 0,74 & PJ2 & 0,84 & CIT3 & 0,79 \\
PROD1 & 0,74 & PROD8 & 0,76 & PJ3 & 0,80 & CIT4 & 0,51 \\
PROD2 & 0,73 & PN1 & 0,87 & PJ4 & 0,84 & CIT7 & 0,71 \\
PROD3 & 0,44 & PN2 & 0,86 & PJ6 & 0,89 & CIT8 & 0,77 \\
PROD4 & 0,43 & PN3 & 0,58 & PJ7 & 0,78 & CIT9 & 0,74 \\
\hline
\end{tabular}


Dari Tabel 6 tentang Loading Factor Indikator penelitian, dapat diketahui bahwa seluruh indikator penelitian memiliki loading factor diatas 0,3 dan karenanya, seluruh indikator tersebut dinyatakan valid dan dapat digunakan.

Analisis Goodness of Fit. Hasil output goodness of fit oleh LISREL ditampilkan pada Tabel 7.

Tabel 7. Hasil Indeks Goodness of Fit

\begin{tabular}{cccc}
\hline No. & Fit Measurement & Score Research & Result \\
\hline 1 & Chi-square & 0.00 & Good fit \\
2 & GFI & 0,87 & Marginal fit \\
3 & RMR & 0,075 & Marginal fit \\
4 & RMSEA & 0,035 & Marginal fit \\
5 & NNFI & 0,96 & Good fit \\
6 & NFI & 0,90 & Marginal fit \\
7 & AGFI & 0,93 & Good fit \\
8 & RFI & 0,68 & Acceptable fit \\
9 & IFI & 0,91 & Good fit \\
10 & CFI & 0,91 & Good fit \\
11 & Df & 3 & Good fit \\
\hline
\end{tabular}

Dari Tabel 7, hasil Indeks Goodness of Fitterlihat bahwa secara keseluruhan, model pada penelitian ini adalah baik.

Analisis Model Struktural. Pengolahan data menggunakan Lisrel, menghasilkan tiga structural equation 1 sampai dengan 3 yaitu:

$$
\begin{aligned}
& \text { Structural Equation } 1 \\
& \text { PUAS }=0,3 \mathrm{PN}+0,17 \mathrm{PROD}, \quad \mathrm{R}^{2}=0,21 \\
& \text { t-values } \quad 2,39 \quad 2,29
\end{aligned}
$$

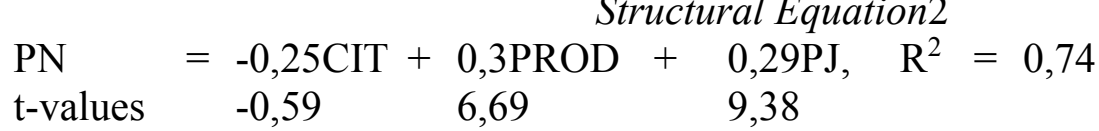

$$
\begin{aligned}
& \text { CIT }=0,81 \text { PROD, } \mathrm{R}^{2}=0,71 \\
& \mathrm{t} \text {-values } \quad 2.22
\end{aligned}
$$

Keterangan: PUAS : Kepuasan Pelanggan; PN : Persepsi Nilai; PROD: Kualitas Produk; CIT : Citra Merek; PJ : Layanan Purna Jual.

Analisis Hipotesis. Hasil nilai thitung sebagaimana tercantum pada Structural Equation 1, 2, dan 3, dapat disimpulkan hipotesis statistik penelitian sebagai berikut: (1) Terdapat pengaruh positif antara kualitas produk (PROD) terhadap kepuasan pelanggan (PUAS); (2) Terdapat pengaruh yang positif antara kualitas produk (PROD)terhadap persepsi nilai (PN); (3) Terdapat pengaruh yang positif antara kualitas produk (PROD)terhadap citra merek (CIT); (4) Terdapat pengaruh yang positif antara layanan purna jual (PJ) terhadap 
persepsi nilai (PN); (5) Citra merek (CIT) Tidak berpengaruh terhadap persepsi nilai (PN); (6) Terdapat pengaruh yang positif antara persepsi nilai (PN) terhadap kepuasan pelanggan (PUAS).

Gambar 2.

Sedangkan Nilai thitung yang digambarkan pada model structuraldisajikan pada

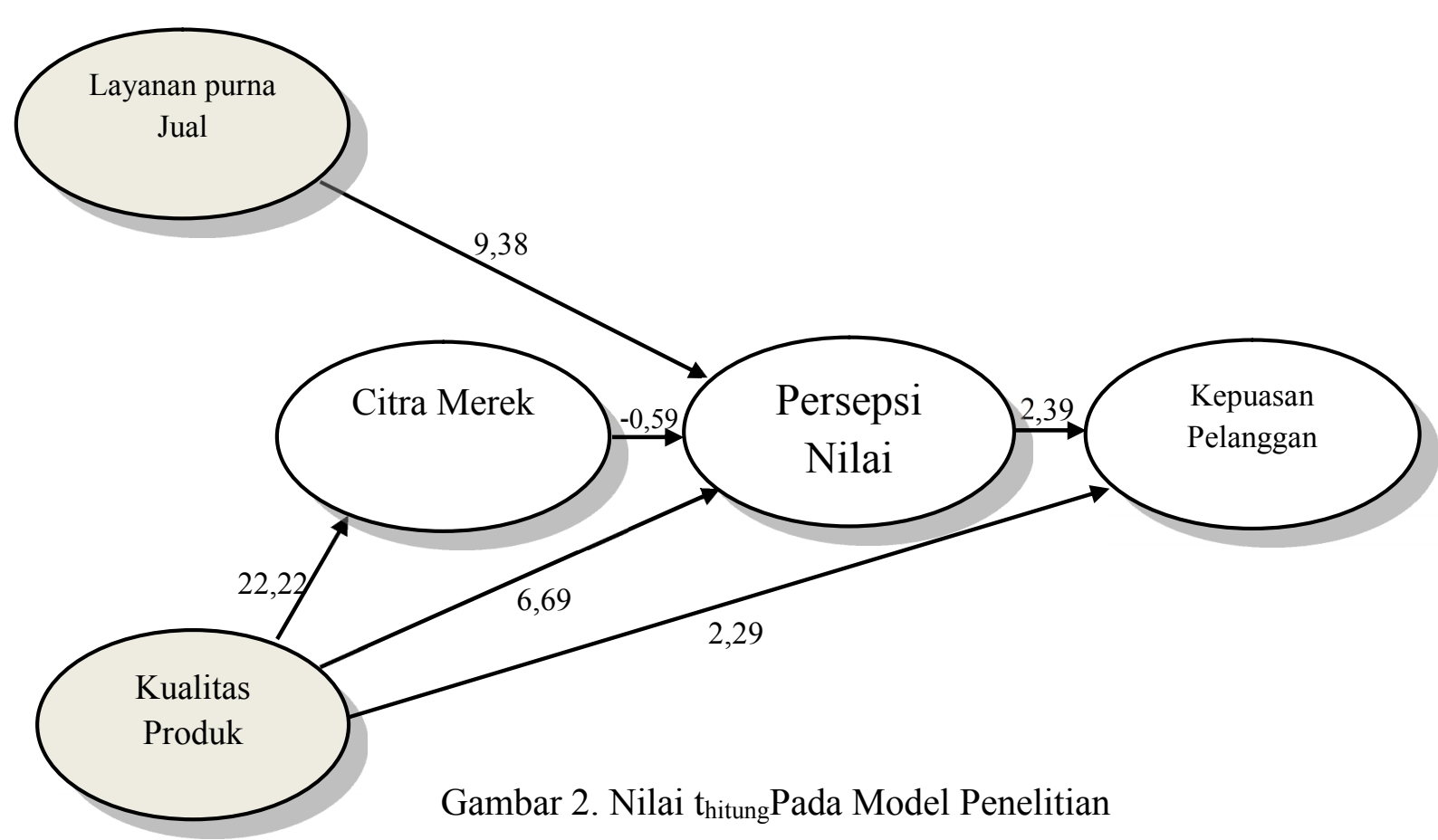

Koefisien Determinasi $\left(\mathbf{R}^{2}\right)$. Hasil perhitungan koefisien determinasi sebagaimana terlihat pada Structural Equation1, nilai $\mathrm{R}^{2}$ sebesar 0.21.Maka dapat disimpulkan bahwa sebesar 21 persen variabel PUAS dapat dijelaskan oleh variabel PN dan PROD, sisanya sebesar 79 persen dijelaskan oleh faktor-faktor lainnya. Pada Structural Equation 2, nilai $\mathrm{R}^{2}$ sebesar 0.74. Maka dapat disimpulkan bahwa sebesar 74 persen variabel $\mathrm{PN}$ dapat dijelaskan oleh variabel CIT, PROD, dan PJ, sisanya sebesar 26 persen dijelaskan oleh faktor-faktor lainnya. Pada Structural Equation 3, nilai $\mathrm{R}^{2}$ sebesar 0.71 Maka dapat disimpulkan bahwa sebesar 71 persen variabel CIT dapat dijelaskan oleh variabel PROD, sisanya sebesar 29 persen dijelaskan oleh faktor-faktor lainnya.

Berdasarkan hasil analisis statistik dan uji hipotesis diperoleh gambaran hubungan antara variabel penelitian. Gambaran ini merupakan respon pembeli kendaraan merek Honda sebagai tanggapan atas kebijakan manajemen produsen kendaraan merek Honda.

Kualitas Produk berpengaruh positif terhadap kepuasan pelanggan. Hal ini sesuai hipotesi penelitian yang dibangun. Selama ini, kualitas produk Honda memang sudah menjadi suatu yang dipercaya oleh masyarakat, terutama untuk Kendaraan produksi Jepang, dapat dikatakan sebagai produk nomor satu dibandingkan yang lainnya. Dari temuan ini berarti produsen Honda masih tetap konsisiten memberikan kepuasan yang baik. Kepuasan yang makin meningkat dapat dilihat dari deskripsi sampel yang $61 \%$ adalah pengguna kendaraan Honda tahun 2012 ke atas. 80\% responden berada pada usia produktif (26-35 tahun), dan 44,5\% kelompok keluarga muda. Pada usia ini umumnya 
orang sangat memperhatikan faktor kenyamanan dan keamanan, diatas pertimbangan harga.

Kualitas produk berpengaruh positif terhadap persepsi nilai. Persepsi dalam penelitian ini persepsi meliputi manfaat dan kualitas dibandingkan dengan harga. Artinya konsumen lebih mendahulukan kualitas dan manfaat dari pada harga. Tetapi akan mempunyai persepsi yang berbeda jika pada merek selain Honda. Dengan kata lain, konsumen lebih memperhatikan kualitas dan manfaat dari pada harga untuk produk Honda, karena jika hanya membandingkan harga dengan produk pesaing, merek Honda mempunyai harga yang relatif lebih mahal untuk banyak varian tipe yang dijualnya.

Kualitas produk berpengruh positif terhadap citra merek. Citra merek digambarkan dalam bentuk rasa aman, mudah dikendarai, dan stabil ketika dipakai. Keunggulan ini karena digunakannya teknoligi yang tinggi. Citra merek digunakan oleh Honda untuk memperkuat kualitas produk. Hal ini berhasil dilakukan Honda.

Layanan purna jual berpengaruh positif terhadap persepsi nilai. Layanan purna jual adalah bentuk lain dari kualitas produk dalam bentuk software. Kebijakan layanan purna jual yang optimal, mampu menjaga kestabilan dari kualitas produk, tingkat keaman bagi pengguna kendaraan. Hal ini meningkatkan persepsi konsumen bahwa Honda sangat serius menjaga dan meningkatkan terus kualitasnnya.

Citra merek tidak berpengaruh terhadap persepsi nilai. Meski tidak berpengaruh, tetapi dilihat dari arah hubungannya adalah negatif. Arah hubungan negatif ini diduga karena Honda telah menjual tipe untuk golongan menengah. Produk ini seperti Mobilio yang kemudian banyak digunakan untuk angkutan taxi. Tipe lain adalah Brio yang dijual dengan harga subsidi. Brio mengesankan jenis yang sempit dan tidak memiliki bagasi. Dua tipe tersebut dibuat dengan harga yang murah, namun untuk spare part tetap mahal. Keadaan demikian telah memberikan persepsi yang buruk bagi Honda yang selama ini mempunyai persepsi yang baik dari sisi masyarakat.

Persepsi nilai berpengaru positif terhadap kepuasan pelanggan. Mobil Honda dipersepsikan sebagai produk yang berkualitas, sehingga meski harganya relatif lebih mahal dibandingkan produk pesaingnya, konsumen tetap bersedia untuk membelinya. Hal ini dapat dilihat dari market share di Indonesia yang dikuasai Honda masih di atas beberapa merek lainnya yang harganya lebih murah. Salah satu pertimbangan konsumen adalah faktor kepuasa yang diberikan Honda cukup tinggi. Hal ini mengacu pada istilah "Harga sebanding dengan kualitas".

\section{PENUTUP}

Kesimpulan. Berdasarkan analisis dan pembahasan mengenai kepuasan pelanggan dalam industri otomotif terhadap 200 responden pelanggan mobil Honda di Indonesia, maka dari analisis dan pembahasan tersebut dapat ditarik kesimpulan sebagai berikut: (1) Kualitas produk berpengaruh positif terhadap kepuasan pelanggan; (2) Persepsi nilaiberpengaruh positif terhadap kepuasan pelanggan; (3) Kualitas produk berpengaruh positif terhadap persepsi nilai; (4) layanan purna jualberpengaruh positif terhadap persepsi nilai; (5) Kualitas berpengaruh positif terhadap citra merek; (6) Citra merek tidak berpengaruh terhadap persepsi nilai

Saran. Berdasarkan hasil penelitian, pembahasan dan kesimpulan yang diperoleh, maka saran yang dapat diberikan adalah sebagai berikut: Pertama. Bagi Honda. Berdasarkan 
hasil penelitian diketahui bahwa kualitas poduk memiliki pengaruh cukup besar terhadap kepuasan pelanggan mobil Hondadi Indonesia. Oleh karena itu kepada Manajemen HONDA disarankan untuk mempertahankan kualitas produk yang baik demi menjaga tingkat kepuasan pelanggan. Dimensi dari kualitas produk Honda yang dapat dipertimbangkan antara lain adalah kinerja,daya tahan, kesesuaian dengan spesifikasi, fitur, reliabilitas, dan estetika. Selain menjaga kualitas produk, untuk menjaga tingkat kepuasan pelanggan mobil Honda yang dimediasi oleh persepsi nilai, peningkatan layanan purna jual juga dapat dilakukan. Unsur-unsur dalam layanan purna jual yang dapat ditingkatkan antara lain adalah garansi, penyediaan aksesoris, layanan pemeliharaan dan perbaikan, fasilitas dan perlengkapan. Kedua. Bagi peneliti selanjutnya. Peneliti selanjutnya dapat memperluas penelitian dengan cara meneliti variabel lain yang berpengaruh terhadap variabel independen seperti pengaruh kecepatan servis berkala terhadap layanan purna jual ataupun pengaruh desain terhadap kualitas produk.

\section{DAFTAR RUJUKAN}

Aaker, A. D. (2008) Manajemen Ekuitas Merek. Jakarta: Mitra Utama.

Arslan, F. M., Altuna, Oylum K., (2010) The effect of brand extensions on product brand image. The Journal of Product and Brand Management. 19(3), 170-180.

Assael, Henry, Nigel P., Linda B.\& Kevin V. (2007) Consumer Behavior.New Jearsey: John Wiley \& Sons.

Barata, A. A. (2006) Dasar-dasar Pelayanan Prima. Cetakan III. Jakarta: PT Gramedia Pustaka.

Chen, Weiping, (2013) Perceived value in community supported agriculture (CSA): A preliminary conceptualization, measurement, and nomological validity. British Food Journal. 115 (10), 1428-1453.

Dharmmesta, B. S. \& Handoko, T. H. (2012) Manajemen Pemasaran Analisis Perilaku Konsumen. Edisi Pertama. Yogyakarta: BPFE.

Durianto, S., Widjaja \& Supraktino. (2003) Invasi Pasar Dengan Iklan Yang Efektif. Jakarta: PT. Gramedia Pustaka Utama.

Garvin, David. (2003) Learning In Action: A Guide To Putting The Learning Organization To Work. Boston: Havard Business Review.

Gaspersz, Vincent. (2006) Total Quality Management (TQM.) Untuk Praktisi Bisnis dan Industri. Jakarta: PT Gramedia Pustaka Utama.

Hawkins, D. I., Mothersbaugh, D. L., \& Best, R. J. (2007) Consumer Behavior: Building Marketing Strategy. New York: McGraw Hill.

Hindle, Tim. (2008) Guide to Management Ideas and Gurus. London: Economist Newspaper Ltd.

Keller, K. L. (2008) Strategic Brand Management: Building, Measuring, and Managing Brand Equity $3^{\text {rd }}$ Edition. New Jersey: Prentice Hall.

Kertajaya, Hermawan. (2006) Marketing Mix. Jakarta : PT. Gramedia Pustaka Umum.

Kotler, P. \& Armstrong, G. (2012) Principle Of Marketing, $14^{\text {th }}$ Edition. New Jersey: Prentice Hall.

Kotler, P. \& Keller K. L. (2011) Marketing Management. $14^{\text {th }}$ Edition. New Jersey: Prentice Hall.

Kuncoro, M. (2013) Metode Riset untuk Bisnis dan Ekonomi. Jakarta: Erlangga. 
Loomis, William R., (1999) Customers Satisfaction Isn't Working. Quality Progress. 32.7, 54-59.

Lovelock, C. \& Wirtz, J. (2015) Service Marketing. Global Edition Jakarta: New Jersey: Prentice Hall.

Mullins, J., Walker Jr, O., Boyd Jr, H. (2008) Marketing Management: A Strategic Decision Making Approach. $6^{\text {th }}$ Ed. New York: McGraw Hills.

Noble. (1999) Development in Marketing Science. Vol. 22, 1-5. Florida: Academy of Marketing Science.

Octama, Carla I. (2015) Honda Targetkan Penjualan 170.000 Unit Mobil. (Retrieved October 25, 2015, from http://www.beritasatu.com/mobil/249670-2015-hondatargetkan-penjualan-170000-unit-mobil.html)

Octavia, Paundrine. (2010) Analisa TingkatKepuasan Pengguna Mobilo Toyota Di Jakarta. Jakarta: Universitas Tarumanagara.

Pardede, Ratlan, Renhard M., (2014) Analisis Jalur Path Analysis Teori dan Aplikasi Dalam Riset Bisnis. Jakarta: Rineka Cipta.

Rangkuti, Freddy (2006) Measuring Customer Satisfaction Teknik Mengukur dan Strategi Meningkatkan Kepuasan Pelanggan dan Analisis Kasus PLN-JP. Jakarta: PT Gramedia Pustaka Utama.

Rusli, A. (2015) Merek Mobil Terlaris Di Indonesia 2014. (Retrieved October 25, 2015,(Retrived

from: http://otomotif.tempo.co/read/news/2015/01/22/123636722/merek-mobil-terlarisdi-indonesia-2014)

Schiffman, L. G \& Kanuk, L. L. (2009) Consumer Behavior. $10^{\text {th }}$ Edition. New Jersey: Prentice Hall.

Sethi, Rajesh. (2000) New Product Quality and Product Development Teams. Journal of Marketing, 64 (2), 1-14

Setiadi, J. N. (2008) Perilaku Konsumen Konsep dan Implikasi untuk Strategi dan Penelitian Pemasaran. Jakarta: Kencana

Simamora, Bilson. (2008) Memenangkan Pasar dengan Pemasaran Efektif dan Profitabel. Jakarta: PT Gramedia Pustaka Utama.

Simorangkir, Pransiscus. (2013) Analisis PengaruhService Quality, Satisfaction, Trust, dan Switching Cost Terhadap Customer Loyalty. Jakarta: Universitas Katolik Indonesia Atmajaya.

Sudarsono \& Edilius. (2010) Manajemen Koperasi Indonesia. Jakarta: Penerbit Rineka Cipta.

Supriadi, A. (2015) Penjualan Masih Lesu Produsen Otomotif Makin Gencar Ekspor.(Retrieved,fromhttp://www.cnnindonesia.com/ekonomi/2015061712412692-60560/penjualan-masih-lesu-produsen-otomotif-makin-gencar-ekspor/October $25,2015)$

Sweeney, J. C., Hausknecht, D., \& Soutar, G. N. (2000) Cognitive Dissonance After Purchase: A Multidimensional Scale. Journal of Psychology \& Marketing. 17 (5): $369-385$

Tjiptono F. (2007) Manajemen Jasa. Yogyakarta: Penerbit Andi.

Waliğora, J. \& Robert Waliğora, (2007) Measuring Customer Satisfaction and Loyalty In The Automotive Industry. Aarhus: Aarhus School of Business.

Wijanto, S. H. (2015) Metode Penelitian Menggunakan Structural Equation Modeling. Jakarta: Lembaga Penerbit FEUI. 
Zeithaml, Valarie A., Mary Jo Bitner, Dwayne D. Gremler. (2006) Service Marketing Integrating Customer Focus Accross The Firm. $4^{\text {th }}$ Edition. New York: McGraw Hill. 